BENM 2021

International Scientific and Practical Conference "Biotechnology, Ecology, Nature Management"

\title{
BIOCHEMICAL STATUS OF RABBIT BLOOD WHEN USING AN ORGANOMINERAL SUPPLEMENT
}

\author{
Natalia A. Golovacheva (a)*, Larisa I. Bychkova (b), Ekaterina A. Safronova (c), \\ Anna Yu. Kondrateva (d) \\ *Corresponding author
}

(a) K. G. Razumovsky Moscow State University of Technologies and Management (the First Cossack University),

Moscow, Russia, n.a.golovacheva@inbox.ru

(b) K.G. Razumovsky Moscow State University of Technologies and Management (the First Cossack University), 73, Zemlyanoy Val str., Moscow, Russia

(c) K.G. Razumovsky Moscow State University of Technologies and Management (the First Cossack University),

73, Zemlyanoy Val str., Moscow, Russia

(d) K.G. Razumovsky Moscow State University of Technologies and Management (the First Cossack University), 73, Zemlyanoy Val str., Moscow, Russia

\begin{abstract}
The article presents the results of experiments to study the effect of an organomineral supplement containing a soluble complex of $\mathrm{Fe}, \mathrm{Mn}, \mathrm{Zn}, \mathrm{Cu}, \mathrm{Co}, \mathrm{Se}$, and I with amino acid derivatives on some biochemical parameters of rabbit blood. It was found that the mineral supplement in the form of chelates did not have a negative effect on the body of the rabbits. The main indicators of protein metabolism characterized the normal state of the body of rabbits, which drank a mineral supplement with water, which as a result was confirmed by a higher level of protein metabolism. Thus, the total protein content in the blood serum of the experimental animals was at the level of $60.5 \pm 3.6 \mathrm{~g} / 1$, which exceeded the control group by $6.32 \%$. The content of albumins and globulins increased by 9.79 and $4.37 \%$, respectively. In the body of rabbits of the experimental group, the level of glucose, as an energy source for ensuring metabolic processes, increased by $35.56 \%(\mathrm{P}<0.01)$ compared to the control. However, all changes in the studied biochemical parameters of the blood occurred within the physiological norm. The use of a complex of mineral substances promotes better assimilation of feed, prevents mineral deficiency, improves metabolism, accelerates growth and ultimately increases the productivity of animals.
\end{abstract}

2672-8575 @ 2022 Published by European Publisher.

Keywords: Albumins, blood chemistry, globulins, organomineral supplement, Rabbits, total protein 


\section{Introduction}

Rabbit breeding is a highly profitable and promising branch of animal husbandry, engaged in breeding the most precocious animals (Karabanova \& Efremov, 2012). Due to their fertility and precocity, rabbits produce a relatively large amount of dietary meat and fur raw materials in a relatively short time (Komlackij et al., 2013).

Rabbit meat is quite easily absorbed by the human body. The amount of protein, vitamins, and minerals in it is higher than in beef, lamb, and pork (Trocenko, 2015). Rabbit meat is recommended for feeding children, nursing mothers, elderly people, as well as people with diseases of the cardiovascular system, stomach, and liver (Gorshkov \& Lipatova, 1987).

Nowadays, the problems of keeping and breeding rabbits have been studied much better than the problems of feeding them, and the influence of various feed additives on the physiological state of rabbits and the quality of the resulting meat has been studied even less (Belov \& Uvarov, 2016). An important task of agriculture is to increase the production of high-quality livestock products. The solution to this problem is considered to be a complete feeding of animals, which is achieved mainly with the help of various mineral additives (Bublik et al., 2003; Golovacheva, Bychkova et al., 2020; Golovacheva, Kozlov et al., 2020; Gubajdullin et al., 2008; Simakov et al., 2020; Nikiforov-Nikishin et al., 2021). It was found that minerals have a positive effect on the metabolic processes and productivity of animals, while increasing the body's resistance to pathogens of infectious diseases (Golovacheva, 2004; Golovacheva, Nikiforov-Nikishin et al., 2019).

Blood is very important in the vital activity of the body: it reflects metabolic processes, characterizes normal and pathological changes (Golovacheva, Kozlov et al., 2020, Tagirov et al., 2012). The serum contains the most protein of all the substances in the dry residue, which consists of amines and globulins. Plasma proteins perform a wide variety of functions.

\section{Problem Statement}

The total amount of protein and its fractions is one of the main biochemical indicators of blood serum (Kalashnikov et al., 2003). Therefore, the study of changes in the biochemical composition of the blood picture is of great diagnostic importance. By observing changes in the biochemical picture of blood, it is possible to assess the metabolic process, the level of feeding and maintenance of animals (Golovacheva, Bychkova et al., 2020; Sidorova et al., 2007).

With intensive growth, the ratio of protein fractions changes. Conversely, with the age of animals, the blood serum becomes more globulins, and the content of albumins, respectively, decreases. The change in the spectrum of serum proteins may be due to a change in animal feeding. Thus, the study of blood biochemical parameters is the main link in the study of blood composition (Golovacheva, Bychkova et al., 2020). 


\section{Research Questions}

The object of the study was rabbits of the California breed kept in the vivarium of the Department of Biology and Ichthyology of Moscow State University of Technology and Management named after K. G. Razumovsky, and the subject of the study was to determine the effectiveness of the mineral supplement influence on some biochemical parameters of the rabbit blood.

\section{Purpose of the Study}

The aim of our work was to study the effect of an organomineral supplement containing a soluble complex of $\mathrm{Fe}, \mathrm{Mn}, \mathrm{Zn}, \mathrm{Cu}, \mathrm{Co}$, Se, and I with amino acid derivatives in the form of a solution on the main biochemical parameters of rabbit blood.

\section{Research Methods}

Scientific research on the effectiveness of the use of organomineral additives in the fattening of rabbits was conducted at the Department of Biology and Ichthyology of Moscow State University of Technology and Management named after K. G. Razumovsky.

The research scheme is presented below (Table 01).

Table 1. Scheme of experiments

\begin{tabular}{cccc}
\hline Rabbits, goal. ( $\mathrm{n}=16)$ & $\begin{array}{c}\text { At the beginning of the } \\
\text { study }\end{array}$ & Feeding ration & $\begin{array}{c}\text { At the end of the study } \\
\text { (after 30 days) }\end{array}$ \\
\hline Control group & $\begin{array}{c}\text { Blood sampling to } \\
\text { determine the biochemical } \\
\text { parameters of rabbit blood }\end{array}$ & $\begin{array}{c}\text { Basic diet (OR) } \\
\text { OP + OMD } \\
\text { ("Helavit") }\end{array}$ & $\begin{array}{c}\text { Blood sampling to determine } \\
\text { the biochemical parameters of } \\
\text { rabbit blood }\end{array}$ \\
\hline
\end{tabular}

Notes: OR - the main diet; OMD-organomineral supplement "Helavit"

For the experiments, 32 heads of rabbits of the California breed at the age of 2 months were selected (Figure 1). The animals were selected according to the principle of analogues. We formed two groups: 1 control group and 1 experimental group, with 16 goals in each group. The live weight of rabbits before the experiment was $1672.21 \pm 28.13$ grams.

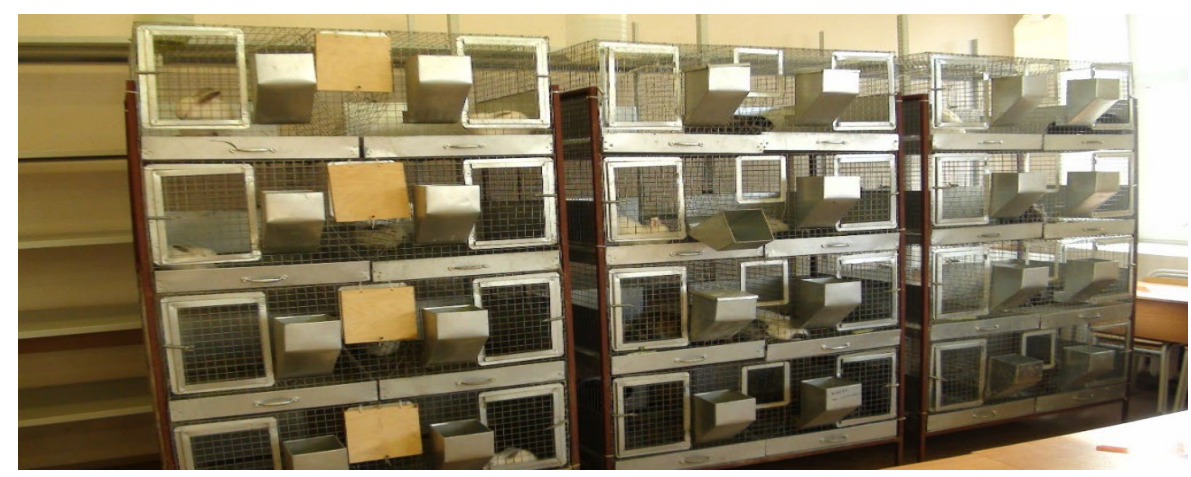

Figure 1. 2 groups of rabbits were formed (control and experience) 
To obtain objective and reliable results, all zootechnical norms for feeding and keeping rabbits in all groups were observed. Feeding in all groups was similar: granulated compound feed Purina (Figure 2). Rabbits were kept in cages with two heads in each. The air temperature in the room was $13-18^{\circ} \mathrm{C}$.

The organomineral supplement "Helavit" was added to the water of the rabbits of the experimental group at the rate of $0.4 \mathrm{ml} /$ head per day. The experiment took place within 30 days. Rabbits of the control group did not receive the drug. During the experiments, the rabbits of both groups had free access to water.

The material for the research was samples of the peripheral blood of rabbits. Biochemical blood tests were performed using classical methods before the studies and on the 30th day of the experiments.

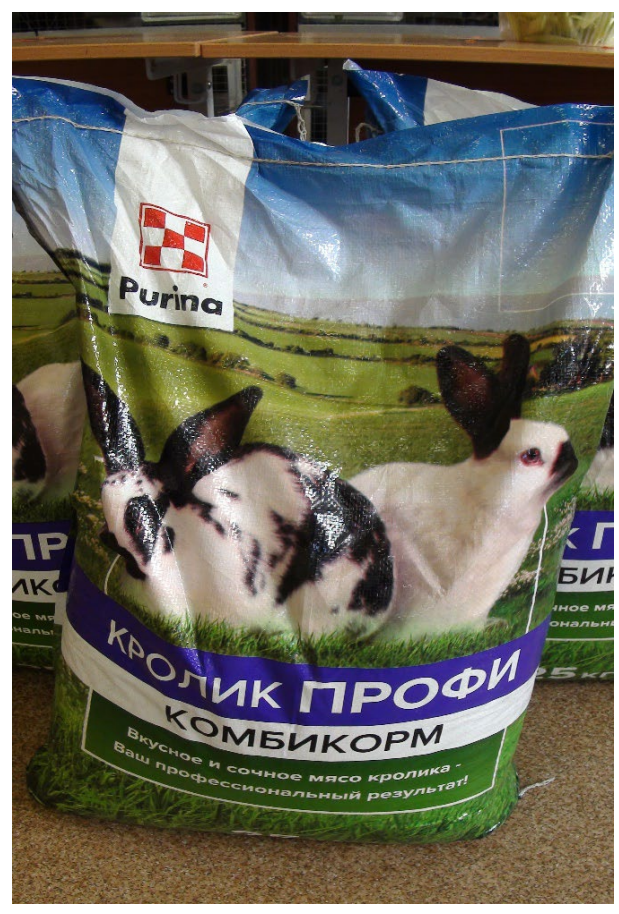

Figure 2. Feeding in all groups was similar: granulated compound feed Purina

The digital material was processed using Microsoft Excel. The reliability of the obtained data was evaluated according to the Student's criterion.

\section{Findings}

Before the use of the organomineral drug, the biochemical parameters of the blood did not have significant differences.

The concentration of total protein is an important indicator that characterizes the effect of feeding on the overall state of the body, since proteins are a plastic material involved in the construction of cells and tissues of the body (Sidorova et al., 2007).

The results obtained on the content of total protein and its fractions in the blood serum of rabbits are presented in Table 2 . 
The mineral supplement in the form of chelates did not have a negative effect on the body of rabbits. Changes in the studied biochemical parameters of the blood occurred within the physiological norm.

Table 2. The content of total protein and its fractions in the blood serum of rabbits

\begin{tabular}{ccccc}
\hline \multirow{2}{*}{ Indicators } & \multicolumn{2}{c}{ Control group } & \multicolumn{2}{c}{ Experimental group } \\
\cline { 2 - 5 } & $\begin{array}{c}\text { Before the } \\
\text { experiments }\end{array}$ & $\begin{array}{c}\text { After the } \\
\text { experiments }\end{array}$ & $\begin{array}{c}\text { Before the } \\
\text { experiments }\end{array}$ & $\begin{array}{c}\text { After the } \\
\text { experiments }\end{array}$ \\
\hline Total protein, g/1 & $53,8 \pm 1,2$ & $56,9 \pm 0,6$ & $54,0 \pm 1,0$ & $* 60,5 \pm 3,6$ \\
Globulins, g/1 & $27,8 \pm 3,3$ & $27,4 \pm 1,7$ & $26,8 \pm 2,2$ & $28,6 \pm 3,2$ \\
Albumins, g/1 & $26,2 \pm 3,3$ & $28,6 \pm 1,4$ & $27,2 \pm 2,7$ & $31,4 \pm 3,2$ \\
\hline Note: $* \mathrm{P}<0.05$ & & & &
\end{tabular}

As a result of the conducted biochemical studies, the level of total protein was higher by $3.6 \mathrm{~g} / \mathrm{l}$ in the blood serum of the experimental group of rabbits, compared to the control (Table 2). Therefore, it can be assumed that the level of metabolic processes in the body of rabbits of the experimental group that consumed the mineral supplement "Helavit" is higher. This may be due to a large number of catalysts, transport proteins, and immunoglobulins.

In the blood serum of rabbits of the experimental group on the 30th day of the study, there was a significant increase in total protein by $6.32 \%$ (P0. 05) due to an increase in the content of albumins.

In our opinion, the mechanism of effect of the product "Helavit" is based on a complex effect on the body of rabbits. Biochemical changes in blood serum may indicate an increase in nonspecific resistance of the body and activation of mineral metabolism in the body of rabbits.

The predominance, in the rabbit blood of both experimental and control groups, of the albumin fraction can be explained by the role of albumins in the synthesis of tissue proteins, since young animals at this age intensively increased their weight.

Albumins perform a transport function, and they are a reservoir of protein, and during prolonged fasting they are used first. At the end of the experiment, the level of albumin in the blood serum of rabbits was at a higher level in the rabbits of the experimental group and was $31.4 \pm 3.2 \mathrm{~g} / \mathrm{l}$, which is $2.8 \mathrm{~g} / 1$ higher than in the control group. This may indicate that the rabbits of the control group had more transport, and, consequently, metabolic processes.

Thus, at the end of the studies, the young animals of the experimental group had albumin values $9.79 \%$ higher than in the control group rabbits. A large number of albumins at this age in rabbits of the experimental group corresponded to large average daily gains in body weight in comparison with the control. As for the content of globulins in the blood serum, the rabbits of the experimental group had an overall increase in the amount of globulins by $4.37 \%$ compared to the control.

It is known that carbohydrates provide support for vital physiological processes occurring in the body. In the digestive tract of rabbits, carbohydrates enter the feed in the form of mono -, di - and polysaccharides. From carbohydrates, the main source of energy in the body is glucose. In the blood, carbohydrates are absorbed in the form of monosaccharides, after which glucose enters the liver, where 3- 
$5 \%$ of it is converted into glycogen, and the rest enters the blood and tissues. It should be noted that glucose is the link between the energy and plastic functions of carbohydrates.

The initial concentration of glucose in the rabbit blood serum is $3.23-3.28 \mathrm{mmol} / \mathrm{l}$ on averaged (Figure 3). The analysis of the data obtained by us allowed to conclude that at the end of the experiments these indicators increased both in the experimental and control groups but did not go beyond the physiological norm.

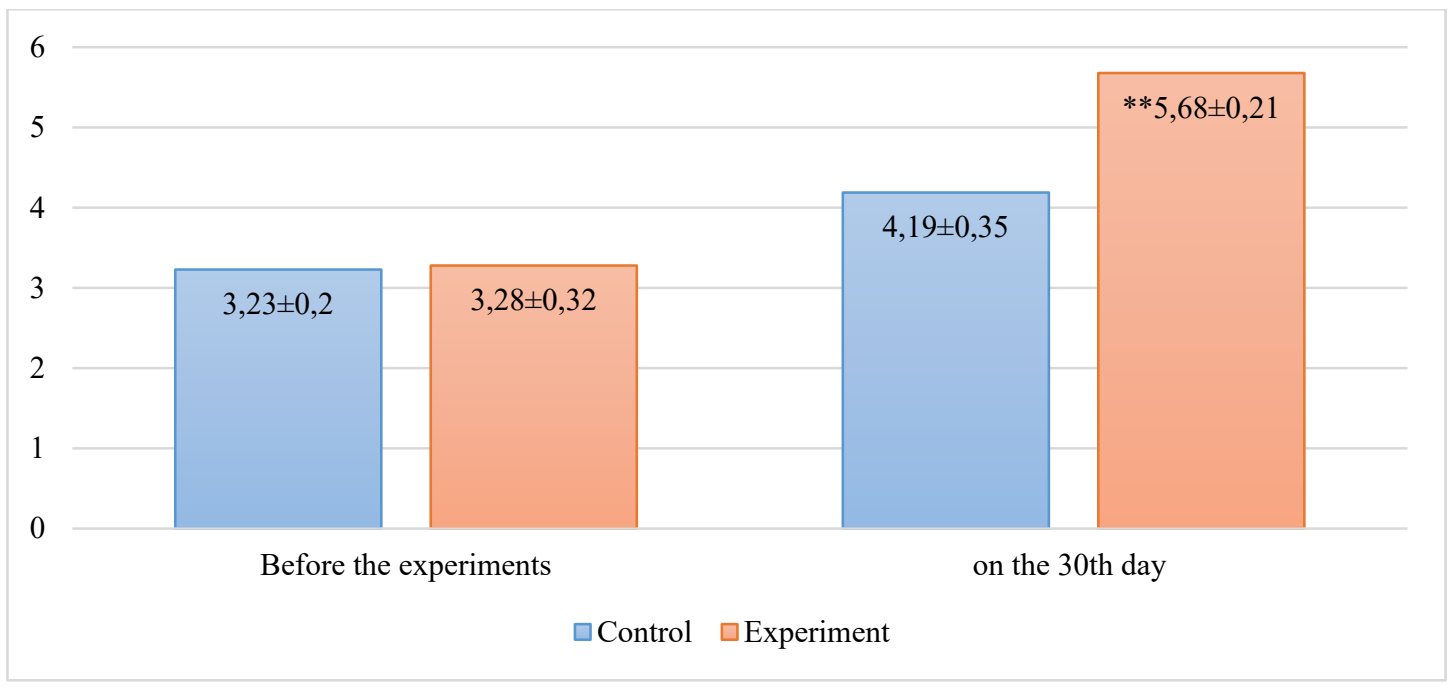

Figure 3. Changes in serum glucose in experimental rabbits, $\mathrm{mmol} / \mathrm{l}$

In the body of rabbits of the experimental group, the level of glucose, as an energy source for ensuring metabolic processes, increased by $35.56 \%(\mathrm{P}<0.01)$ compared to the control.

\section{Conclusion}

1. The positive effect of chelates on the biochemical parameters of the blood serum of rabbits was established. The main indicators of protein metabolism characterized the normal state of the body of rabbits, which drank a mineral supplement with water, which as a result was confirmed by a higher level of protein metabolism. Thus, the total protein content in the blood serum of the experimental animals was at the level of $60.5 \pm 3.6 \mathrm{~g} / 1$, which exceeded the control group by $6.32 \%$. The content of albumins and globulins increased by 9.79 and $4.37 \%$, respectively. Changes in the studied biochemical parameters of the blood occurred within the physiological norm.

2. Indicators of the amount of glucose increased in both experimental and control groups but did not go beyond the physiological norm. However, in the body of rabbits of the experimental group, the level of glucose, as an energy source for providing metabolic processes, increased by $35.56 \%(\mathrm{P}<0.01)$ compared to the control. 


\section{References}

Belov, A. A., \& Uvarov, R. A. (2016). Sostoyanie i tendencii razvitiya melkotovarnogo proizvodstva krol'chatiny [State and development trends of small-scale production of rabbit meat in the Russian Federation]. Tekhnologii $i$ tekhnicheskie sredstva mekhanizirovannogo proizvodstva produkcii rastenievodstva i zhivotnovodstva, 167-175.

Bublik, V. N., Simonovich, V. N., Ladysh, I. A., Golovacheva, N. A., \& Krinichnyj, A. N. (2003). Vliyanie prirodnyh mineralov-ceolitov na klinicheskie i biohimicheskie pokazateli krovi krolikov [Influence of natural minerals-zeolites on clinical and biochemical parameters of the blood of rabbits]. Veterinary medicine: Interdepartmental thematic scientific collection, 82, 113-115.

Golovacheva, N. A. (2004). Vliyanie ceolitov na pokazateli estestvennoj rezistentnosti krovi porosyat pri iersinioze [Influence of zeolites on indices of natural blood resistance of piglets with yersiniosis]. Collection of scientific works of Lugansk NAU, 35/47, 29-32.

Golovacheva, N. A., Bychkova, L. I., Brezhnev, L. L., Ivanova, Y. S., \& Klimov, V. A. (2020). Study of the effect of feed zeolites supplements of the Kholinsky deposit on hematological parameters of representatives of the Leporidae family. In IOP Conference Series: Earth and Environmental Science (Vol. 421, No. 3, p. 032027). IOP Publishing. https://doi.org/10.1088/1755$1315 / 421 / 3 / 032027$

Golovacheva, N. A., Kozlov, A. V., \& Klimov, V. A. (2020). Vliyanie yantarnoj kisloty na dinamiku zhivoj massy krolikov [Influence of succinic acid on the dynamics of the live weight of rabbits]. Bulletin of the Kursk State Agricultural Academy, 5, 117-123.

Golovacheva, N. A., Nikiforov-Nikishin, A. L., Gorbunov, A. V., Kozlov, A. V., Tkachev, A. V., \& Tkacheva, O. L. (2019). Holinskie ceolity v sisteme profilaktiki sal'monelleznoj infekcii zhivotnyh [Choline zeolites in the system for the prevention of Salmonella infection in animals]. Veterinary medicine, 9, 19-22. https://doi.org/10.30896/0042-4846.2019.22.9.19-22

Gorshkov, A. I., \& Lipatova, O. V. (1987). Gigiena pitaniya [Food hygiene]. Medicina.

Gubajdullin, N. M., Zajnukov, R. C., Mironova, I. V., \& Tagirov, H. H. (2008). Gematologicheskie pokazateli korovpervotyolok bestuzhevskoj porody pri ispol'zovanii alyumosilikata glaukonita [Hematological parameters of cows of the Bestuzhev breed with the use of aluminosilicate glauconite]. Izvestiya Orenburgskogo gosudarstvennogo agrarnogo universiteta, 1(17), 111-113.

Kalashnikov, A. P., Fisinin, V. I., Shcheglov, V. V., Pervoe, N. G., Kleimenov, N. I., Strekozov, N. I., Kalyshtsky, B. D., Egorov, I. A., Makhaev, E. A., Dvalishvili, V. G., Kalashnikov, V. V., Vladimirov, V. L., Gruzdev, N. V., Mysik, A. T., Balakirev, N. A., \& Bugdaev, I. E. (2003). Normy i raciony kormleniya sel'skohozyajstvennyh zhivotnyh [Rates and rations for feeding farm animals]. Russian Agricultural Academy.

Karabanova, L. V., \& Efremov, A. P. (2012). Krolikovodstvo i sovremennye tekhnologii ego vedeniya [Rabbit breeding and modern technologies for its management]. Dynamics of systems, mechanisms and machines (Agrobiotechnology), 5, 122-124. https://cyberleninka.ru/article/n/krolikovodstvo-isovremennye-tehnologii-ego-vedeniya

Komlackij, V. I., Loginov, S. V., Komlackij, G. V., \& Ignatenko, Y. A. (2013). Effektivnoe krolikovodstvo [Effective rabbit breeding]. KubGAU.

Nikiforov-Nikishin, D. L., Kochetkov, N. I., Bugaev, O. D., \& Ponomarev, A. K. (2021, March). The influence of the organo-mineral complex on the growth dynamics of the Scenedesmus quadricauda culture. In IOP Conference Series: Earth and Environmental Science (Vol. 689, No. 1, p. 012039). IOP Publishing. https://doi.org/10.1088/1755-1315/689/1/012039

Sidorova, K. A., Esenbaeva, K. S., Petrova, N. A., \& Bektasheva, A. A. (2007). Vliyanie probiotikov na pokazateli krovi krolikov [The effect of probiotics on blood counts in rabbits]. Bulletin of the Tyumensuk State Agricultural Academy Tyumen, 1, 162-163.

Simakov, G., Nikiforov-Nikishin, A., Nikiforov-Nikishin, D., Beketov, S., Kochetkov, N., \& Klimov, V. (2020). Histological changes in the liver, intestines and kidneys of Clarias gariepinus when using feed with chelated compounds. International Journal of Pharmaceutical Research, 12(03), 312385. https://doi.org/10.31838/ijpr/2020.12.03.331 
Tagirov, H. H., Vagapov, F. F., \& Mironova, I. V. (2012). Gematologicheskie pokazateli bychkov chyorno-pyostroj porody pri ispol'zovanii probioticheskoj kormovoj dobavki «Biogumitel'» [Hematological indicators of black-and-white bulls when using the probiotic feed additive "Biohumitel"]. Bulletin of beef cattle, 4(78), 60-66.

Trocenko, I. V. (2015). Produktivnye kachestva krolikov [Productive qualities of rabbits]. Innovative ways of developing animal husbandry in the XXI century. Materials of the scientific and practical conference with international participation (pp. 66-70). Omsk. 